\title{
PERSEPSI MASYARAKAT TERHADAP DAMPAK LINGKUNGAN KEGIATAN REHABILITASI DAERAH IRIGASI BENDO DI KABUPATEN PONOROGO
}

\author{
Primanda Kiky Widyaputra \\ Warniningsih \\ Fakultas Teknologi Sumberdaya Alam \\ Institut Teknologi Yogyakarta
}

\begin{abstract}
ABSTRAK
Pengamanan ketahanan pangan menjadi salah satu sasaran pembangunan ekonomi nasional pemerintah Republik Indonesia. Oleh karena itu, perencanaan sarana dan prasarana irigasi penting dilaksanakan dalam rangka mewujudkan infrastruktur irigasi yang baik untuk mendukung ketahanan pangan.Kegiatan rehabilitasi daerah irigasi ini berkaitan dengan karakter penduduk di Ponorogo yang sebagian besar bermatapencaharian sebagai petani, sehingga tersedianya DI. Bendo dapat mendukung kegiatan pertanian masyarakat. Tujuan penelitian ini yaitu menganalisis persepsi dan penerimaan masyarakat terhadapdampak lingkungan kegiatan rehabilitasi Daerah Irigasi Bendo di Ponorogo. Metode pengambilan data dilakukan melalui wawancara dengan penduduk dengan menggunakan kuesioner. Responden diambil dari masyarakat yang diperkirakan akan terkena dampak langsung. Wawancara dan penyebaran kuesioner kepada minimal 3 (tiga) responden per desa yang bisa mewakili kondisi di lokasi kegiatan. Metode analisis dilakukan dengan analisis kualitatif dan kuantitatif.Hasil analisis menunjukkan bahwa masyarakat sepenuhnya mendukung program pembangunan DI. Bendo. Hal tersebut dikarenakan masyarakat merasa akan mendapatkan dampak positif dari kegiatan tersebut. Persepsi masyarakat terhadap rencana rehabilitasi D.I. Bendo adalah mendukung rencana kegiatan tersebut dan bahwa keberadaan jaringan irigasi sangat bermanfaat bagi masyarakat.
\end{abstract}

Katakunci: Irigasi, Persepsi, Dampak, Lingkungan 


\title{
PUBLIC PERCEPTIONS OF ENVIRONMENTAL IMPACT OF BENDO IRRIGATION REHABILITATION IN PONOROGO REGENCY
}

\begin{abstract}
Food security become one of the national focal points for economic development in Indonesia. Irrigation infrastructure is important to be implemented within the context of supporting national food security. Irrigation rehabilitation projects is conducted to support agriculture in the community.The purpose of this research is to analyzethe perception and acceptance of public with the environment impact of Bendo irrigation rehabilitation projects. The researchis conducted through interviews with the inhabitants near the project location using questionnaire. The questionnaires given to a minimum of three respondents per village. Analysis is conducted using qualitative and quantitative analysis. The results of the analysis shows that the people support the projects and willing to accept the positive impact of the project. The perception of the community towards the rehabilitation plan of Bendo irrigation system is to support the plan of the project. The other perception is that the existence of irrigation network is very beneficial for the people.
\end{abstract}

Keywords:Irrigation, Perception, Impact, Environment

\section{A. PENDAHULUAN}

\begin{tabular}{lrr}
\multicolumn{2}{c}{ Rencana } & Pembangunan \\
Jangka & Menengah & Nasional \\
(RPJMN) & $2015-2019$ & menyatakan \\
bahwa pengamanan & ketahanan \\
pangan menjadi salah & satu & sasaran \\
pembangunan ekonomi & nasional \\
pemerintah Republik Indonesia. Oleh \\
karena itu, perencanaan & sarana dan \\
prasarana & irigasi & penting \\
dilaksanakan & dalam & rangka \\
mewujudkan infrastruktur & irigasi \\
yang baik untuk & mendukung \\
ketahanan pangan. &
\end{tabular}

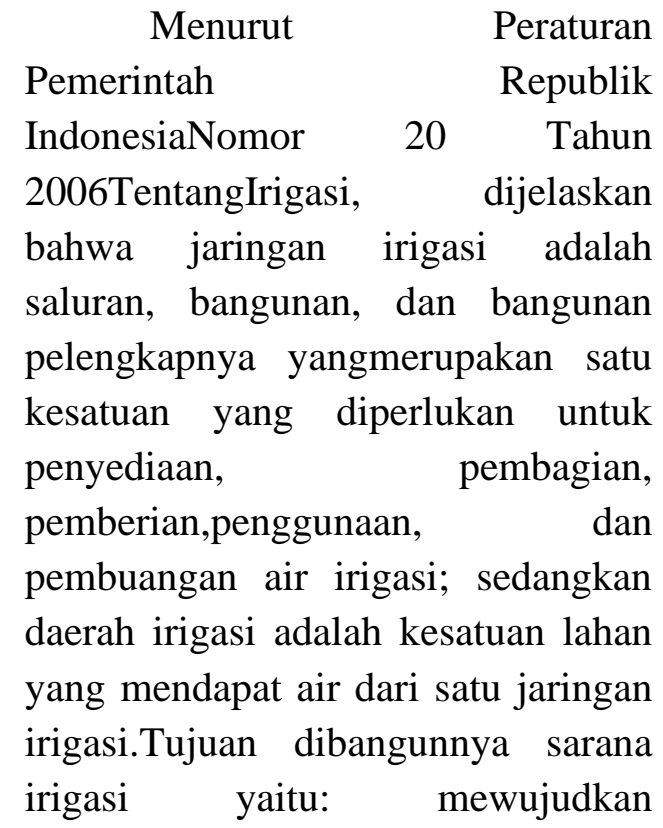


kemanfaatan airyang menyeluruh, terpadu dan berwawasan lingkungan serta untuk meningkatkankesejahteraan masyarakat, khususnya petani dan mempertahankan sertameningkatkan produktivitas lahan untuk mencapai hasil pertanian yang optimal tanpa mengabaikan kepentingan yang lain (Suhardjono, 1994).

Pemanfaatan saluran irigasi terhadap kesejahteraan para petani sudah tidak lagi kesulitan dalam mengairi lahan pertanian mereka karena sudah adanya sistem irigasi yang akan selalu menyalurkan sumber air yang tak pernah berhenti. Sistem irigasi ini bisa dibuka tutup, sehingga kapan saja petani membutuhkan air untuk lahan pertanian mereka, tinggal membuka saluran air tersebut. Pemerintah sudah memberikan fasilitas irigasi dan membangun sistem irigasi untuk dimanfaatkan oleh para petani.

Kegiatan rehabilitasi daerah irigasi ini berkaitan dengan karakter penduduk yang sebagian besar bermatapencaharian sebagai petani, sehingga tersedianya DI. Bendo dapat mendukung kegiatan pertanian masyarakat. Corak usaha tani di Kabupaten Ponorogo sebagian masih bersifat sub sistem sehingga faktor keramahan alam menjadi sangat dominan pengaruhnya terhadap kuantitas dan kualitas produksi. Karena itu, sesuai kondisi usaha tani yang masih sub sistem, pembangunan pertanian yang berwawasan lingkungan dalam rangka menjaga kelestarian ekosistem alam akan terasa sangat bermanfaat untuk kelanjutan usaha tani. Rata-rata kepemilikan lahan pertanian terluas adalah Sawah seluas $2.916 \mathrm{~m}^{2}$, tegalan dengan luas $624 \mathrm{~m}^{2}$, pekarangan $433 \mathrm{~m}^{2}$, kebun $74 \mathrm{~m}^{2}$, sementara keberadaan kolam perikanan sangatlah kecil. Pola tanam yang dilakukan oleh petani di daerah studi $96 \%$ adalah Padi-PadiPalawija, hanya sebagian kecil saja (sebesar 4\%) yang melakukan Pola Tanam Padi-Padi-Bera dengan alasan ketersediaan air irigasi yang terbatas. Hal tersebut mendasari pentingnya rehabilitasi DI. Bendo yang terletak $\pm 23 \mathrm{~km}$ disebelah Selatan Kota Ponorogo. Berdasarkan latar belakang dan permasalahan yang dijumpai, maka dirumuskan tujuan penelitian ini yaitu menganalisis persepsi dan penerimaan masyarakat terhadap dampak lingkungan kegiatan rehabilitasi Daerah Irigasi Bendo di Ponorogo.

\section{B. TINJAUAN PUSTAKA \\ 1. Jaringan Irigasi}

Jaringan irigasi adalah saluran, bangunan, dan bangunan pelengkapnya yang merupakan satu kesatuan yang diperlukan untuk penyediaan, pembagian, pemberian, penggunaan, dan pembuangan air irigasi. Saluran irigasi merupakan infrastruktur yang mendistribusikan air yang berasal dari Bendungan/ Bendung/ Embung kepada lahan 
pertanian yang dimiliki oleh masyarakat (Sosrodarsono,1999).

\section{Tujuan dan Manfaat Sistem Irigasi}

a. Fungsi dan Tujuan Sistem Irigasi

Peraturan Pemerintah

Republik IndonesiaNomor 20 Tahun 2006TentangIrigasimenyebutkan

bahwa irigasi berfungsi mendukung produktivitas usaha tani guna meningkatkan produksipertanian dalam rangka ketahanan pangan nasional dan kesejahteraan masyarakat,khususnya petani, yang diwujudkan melalui keberlanjutan sistem irigasi.Tujuan irigasi secara langsung adalah membasahi tanah, agar dicapai suatu kondisi tanah yang baik untuk pertmbuhan tanaman dalam hubungannya dengan persentase kandungan air dan udara diantara butir-butir tanah. Pemberian air dapat juga mempunyai tujuan sebagai pengangkut bahan-bahan pupuk untuk perbaikan tanah.Tujuan irigasi secara tidak langsung adalah pemberian air yang dapat menunjang usaha pertanian melalui berbagai cara antara lain mengatur suhu tanahdan membersihkan tanah (Kementerian Pekerjaan Umum, dalam Standar Perencanaan Irigasi, 2013)

b. Manfaat Sistem Irigasi

Beberapa manfaat irigasi diantaranya adalah: melancarkan aliran air ke lahan sawah, mencukupi kebutuhan air pada lahan pertanian, dan mempermudah petani untuk mengairi lahan, dan sebagai salah satu sarana pendukung ketahanan pangan.

\section{Persepsi}

Persepsi adalah proses yang digunakan individu mengelola dan menafsirkan kesan indera mereka dalam rangka memberikan makna kepada lingkungan mereka. Persepsi adalah suatu proses yang dilalui oleh suatu stimulus yang diterima panca indera yang kemudian diorganisasikan dan diinterpretasikan sehingga individu menyadari yang diinderanya itu. Persepsi adalah proses dimana kita menafsirkan dan mengorganisasikan pola stimulus dalam lingkungan. Sebagai cara pandang, persepsi timbul karena adanya respon terhadap stimulus (Atkinson dan Hilgard, 2011).

\section{METODE PENELITIAN}

\section{Lokasi Penelitian}

Secara adiministrasi rencana areal irigasi Bendo adalah terletak di beberapa kecamatan, yaitu Kecamatan Sawoo, Kecamatan Sambit, Kecamatan Jetis, Kecamatan Mlarak, Kecamatan Ponorogo Kota, Kabupaten Ponorogo. Batas-batas wilayah sebagai berikut :

- Sebelah Utara : Kabupaten Madiun, Magetan dan Nganjuk

- Sebelah Timur : Kabupaten Trenggalek dan Tulungagung 
- Sebelah Selatan : Kabupaten Pacitan

- Sebelah Barat : Kabupaten Pacitan dan Wonogiri

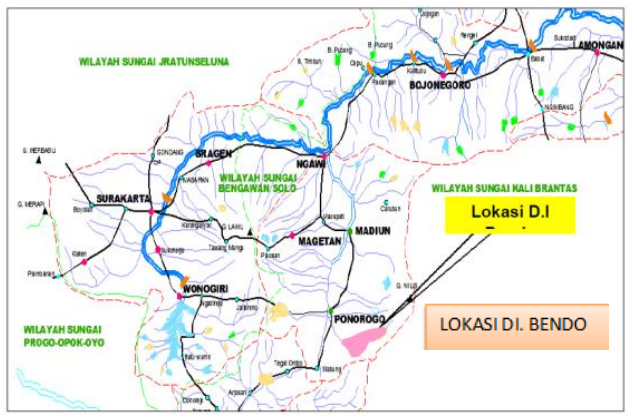

Gambar 1. Peta Lokasi Penelitian

\section{Tahapan Penelitian}

Penelitian ini dilakukan melalui beberapa tahapan sebagai berikut:

a. Pengumpulan Data Sekunder

Jenis kegiatan yang dilakukan antara lain: Mengumpulkan studi-studi lingkungan yang pernah dilakukan, dan mengumpulkan data demografi penduduk.

b. Survei dan Pengambilan Data, menggunakan kuesioner

c. Analisis Data analisis data kuantitatif dan kualitatif.

\section{Metode Pengambilan Data}

Data diperoleh melalui wawancara dengan penduduk di lokasi terdekat dengan rencana lokasi kegiatan dan daerah manfaat dengan menggunakan kuesioner.Responden diambil dari masyarakat yang diperkirakan akan terkena dampak langsung, dengan metode "Purposive
Sampling".Sistem pengambilan kuesioner dilakukan dengan door to door.Wawancara dan penyebaran kuesioner kepada minimal 3 (tiga) responden per desa yang bisa mewakili kondisi di lokasi kegiatan.

\section{Metode Analisis Data}

Metode yang digunakan disesuaikan dengan jenis data yang akan dianalisis yaitu analisis data kuantitatif untuk data-data numerik dan analisis kualitatif yang berupa persepsi yang berlaku di masyarakat. Persepsi dianalisis menggunakan metode analisis deskriptif.

\section{HASIL DAN PEMBAHASAN}

a. Dampak Lingkungan Kegiatan Rehabilitasi Daerah Irigasi DI. Bendo.

Dampak Lingkungan Kegiatan Rehabilitasi Daerah Irigasi DI. Bendo dirangkum berdasarkan studi pengelolaan dan pemantauan lingkungan dan melalui observasi lapangan. Kegiatan ini dilakukan untuk memprediksi dampak lingkungan yang dapat terjadi pada proses rehabilitasi dan operasional irigasi.

Kegiatan-kegiatan pada tahap persiapan kontruksi yang dapat menimbulkan dampak terhadap lingkungan pada saat persiapan adalah rekruitmen tenaga kerja, dan pembuatan dan operasional barak kerja / base camp, serta mobilisasi material dan alat-alat berat.Lingkungan yang terkena 
dampak dari kegiatan-kegiatan pada tahap ini adalah terjadinya penurunan kualitas udara disekitar daerah jalur lintasan transportasi kendaraan, gangguan pada sumber daya lahan dan sumberdaya biologi serta gangguan pada lingkungan sosial ekonomi dan sosial budaya penduduk setempat. Dampak negatif yang ditimbulkan bersifat langsung dan telah terjadi pada saat pekerjaan saluran. Dampak yang terjadi ini hanya berlangsung selama kegiatan persiapan konstruksi dan merupakan dampak sesaat.

Dampak pada tahap pelaksanaan kontruksiyang berpotensi menimbulkan dampak terhadap lingkungan adalah kegiatan pekerjaan pembersihan lahan, galian tanah dan pengangkutan tanah, pembangunan jaringan irigasi dan fasilitas pelengkapnya, demobilisasi tenaga kerja. Kegiatan ini dapat menyebabkan terjadinya penurunan kualitas udara pada lingkungan pemukiman yang dilalui jalur transportasi, lingkungan sosial ekonomi dan budaya serta terganggunya prasarana jalan umum. Lingkungan yang telah terkena dampak adalah pada daerah sepanjang jalur transportasi dan lingkungan pemukiman disekitar jalur transportasi tersebut, serta di sekitar area pembangunan bangunan irigasi. Dampak negatif yang telah ditimbulkan ini hanya terjadi selama kegiatan konstruksi masih berlangsung. Sementara itu di lingkungan sosial ekonomi dan budaya penduduk disekitar tapak kegiatan akan menerima dampak positif dan negatif dengan adanya kegiatan-kegiatan pada tahap ini.

Dampak positif terjadi dengan adanya peluang berusaha dan bekerja bagi penduduk terutama untuk pekerjaan bangunan bendung dan jaringan irigasi. Sedangkan dampak negatif terjadi sebagai akibat menurunnya kualitas udara dan meningkatnya kebisingan serta gangguan pada kelancaran mobilitas harian penduduk. Dampak negatif yang terjadi ini, masih merupakan dampak sesaat dan terjadi selama kegiatan konstruksi berlangsung.

Dengan telah direhabilitasi jaringan irigasi akan menimbulkan dampak positif maupun dampak negatif bagi penduduk disekitar tapak kegiatan. Dampak positif yang ditimbulkan adalah, lebih terbukanya lapangan berusaha dan bekerja bagi penduduk dalam menggarap lahan yang tersedia, meningkatnya perekonomian penduduk. Dampak pada tahap operasi dan pemeliharaan ini akan terjadi selama jaringan 
irigasi ini masih dapat dimanfaatkan.

b. Persepsi dan Penerimaan Masyarakat

Hasil pengumpulan data mencakup proses wawancara melalui penyebaran kuesioner kepada masyarakat yang tinggal dan merasakan dampak dari rehabilitasi DI. Bendo. Analisis persepsi masyarakat bertujuan untuk mengetahui persepsi dan aspirasi masyarakat sekitar dalam rehabilitasi DI. Bendo. Hasil ini penting untuk mengetahui sejauh mana penerimaan masyarakat terhadap kegiatan.Berikut hasil dari analisis:

1) Persepsi Masyarakat

Hasil analisis menunjukkan bahwa masyarakat sepenuhnya mendukung program rehabilitasi DI. Bendo. Hal tersebut dikarenakan masyarakat merasa akan mendapatkan dampak positif dari kegiatan tersebut.

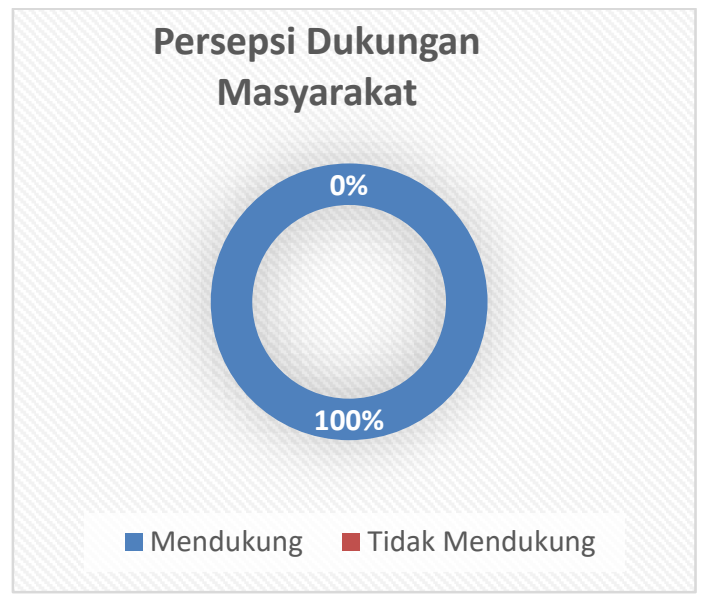

Gambar 2. Persepsi Dukungan

Masyarakat

b) Persepsi Masyarakat Terhadap Manfaat Jaringan Irigasi

Hasil analisis menunjukkan bahwa 90\% masyarakat yakin jika kegiatan DI. Bendo sangat bermanfaat, sedangkan 10\% yakin jika akan bermanfaat. Dapat disimpulkan bahwa secara menyeluruh masyarakat sadar akan pentingnya manfaat rehabilitasi DI. Bendo.

Persepsi masyarakat Terhadap Manfaat Jaringan Irigasi

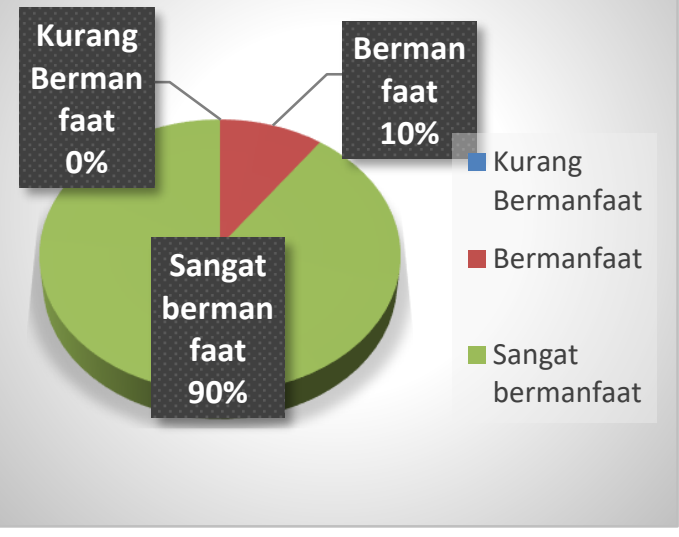

Gambar 3. Persepsi Terhadap Manfaat Jaringan Irigasi

c) Kesediaan Penggunaan Lahan Masyarakat untuk RehabilitasiJaringan Irigasi

Analisis bertujuan untuk melakukan penerimaan dari rehabilitasi DI. Bendo yang akan menggunakan sebagian lahan dari masyarakat. Analisis ini penting agar meminimalkan risiko konflik lahan saat rehabilitasi dilakukan. Hasil analisis menunjukkan bahwa lahan masyarakat rela jika lahannya 
digunakan untuk rehabilitasi secara sukarela dengan persentase $26 \%$. Elemen masyarakat lainnya menyetuji jika lahannya digunakan namun dengan syarat tertentu, seperti rela dengan imbalan sebanyak $29 \%$ dan rela dengan pengganti harga lahan sesuai harga pasar $45 \%$.

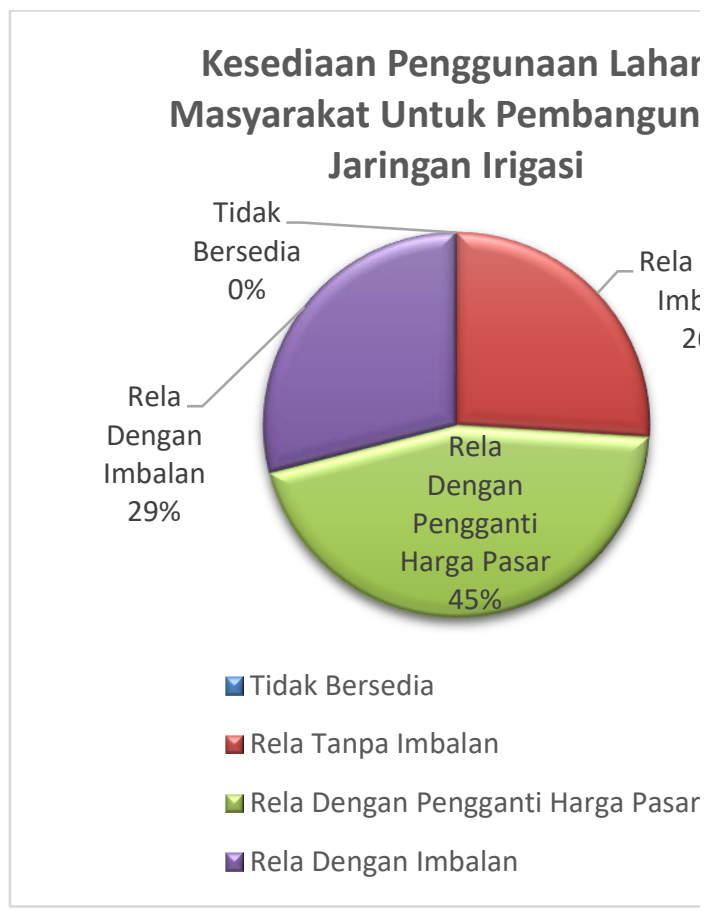

Gambar 4. Kesediaan Penggunaan

Lahan Masyarakat untuk Rehabilitasi

DI. Bendo

d) Kesediaan Masyarakat untuk

Partisipasi Secara Gotong

Royong

Analisis bertujuan untuk mengatahui kesediaan masyarakat berpartisipasi untuk gotong royong membangun dan merawat bangunan irigasi. Hasil analisis menunjukkan bahwa secara menyeluruh masyarakat bersedia untuk ikut gotong royong membangun dan merawat jaringan irigasi.

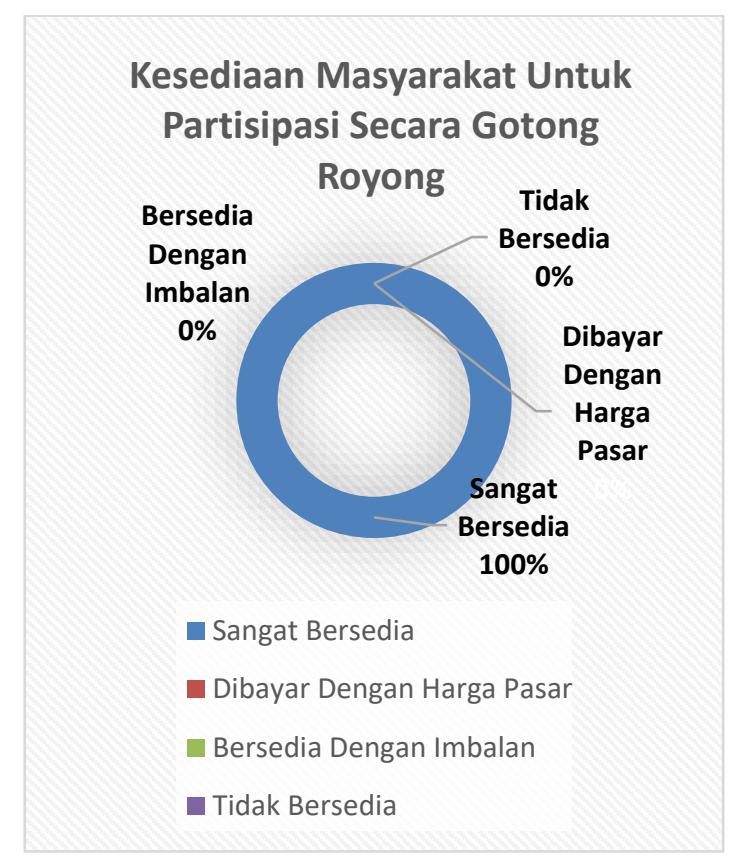

Gambar 5. Kesediaan Masyarakat untuk Partisipasi Gotong Royong Rehabilitasi DI. Bendo

e) Kesediaan Masyarakat Atas Kerjasama Pengaturan Air Irigasi Analisis bertujuan untuk mengatahui kesediaan masyarakat atas kerjsama dalam pengaturan air irigasi. Hasil analisis menunjukkan bahwa secara menyeluruh masyarakat bersedia untuk ikut gotong royong membangun dan merawat jaringan irigasi. 


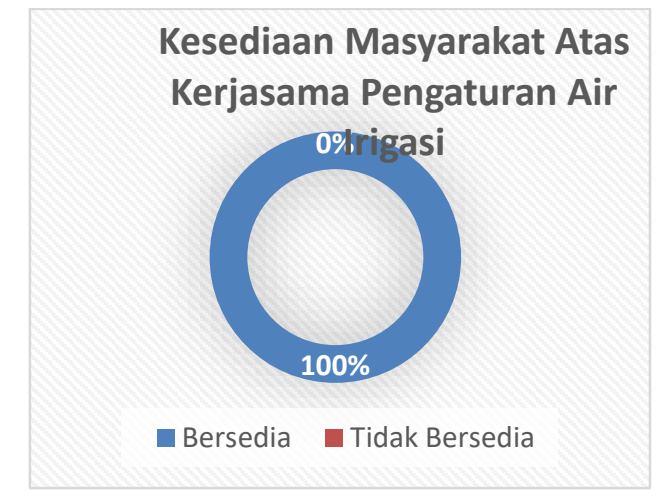

Gambar 6. Kesediaan Masyarakat atas Kerjasama Pengaturan Air Irigasi DI. Bendo

f) Kesediaan Masyarakat Dalam Membayar Iuran Pengelolaan Air Irigasi

Analisis bertujuan untuk mengetahui kesediaan masyarakat dalam memberikan iuran rutinn untuk kegiatan pengelolaan air irigasi. Hal tersebut penting untuk mengetahui tingkat kesadaran masyarakat dalam kegiatan pengelolaan dan perawatan bangunan irigasi. Hasil analisis menunjukkan bahwa secara umum dalam persentase $86 \%$ masyarakat bersedia untuk aktif iuran sedangkan 14\% masyarakat menolak untuk iuran.

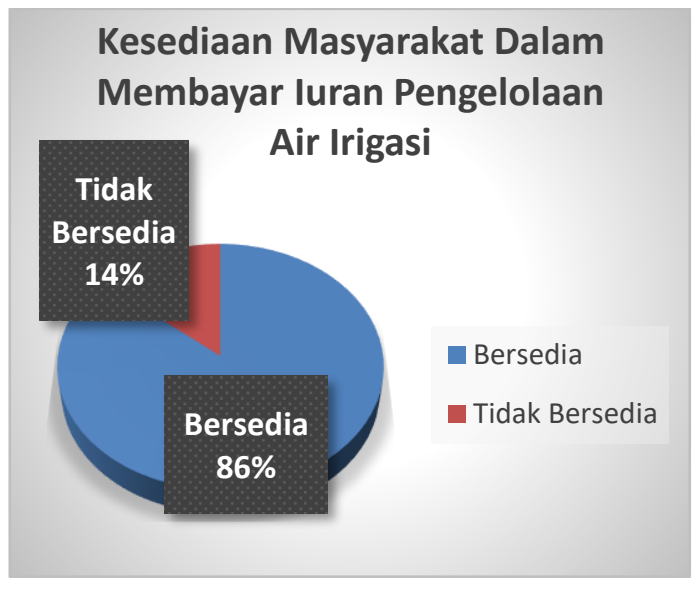

Gambar 7. Kesediaan Masyarakat dalam Membayar Iuran Pengelolaan Air Irigasi DI. Bendo

g) Keberadaan Organisasi Pengelolaan Air Irigasi dan Aktif Menjadi Anggota

Analisis bertujuan untuk mengatahui kesediaan setelah rehabilitasi DI. Bendo dibentuk organisasi masyarakat pengelola air irigasi serta masyarakat aktif menjadi pengurus dan anggota. Hal tersebut penting untuk mengetahui tingkat kesadaran masyarakat dalam kegiatan pengelolaan dan perawatan bangunan irigasi. Hasil analisis menunjukkan bahwa secara menyeluruh masyarakat setuju $100 \%$ jika ada organisasi khusus pengelola air irigasi dan masyarakat memegang peran aktif di organisasi tersebut. 


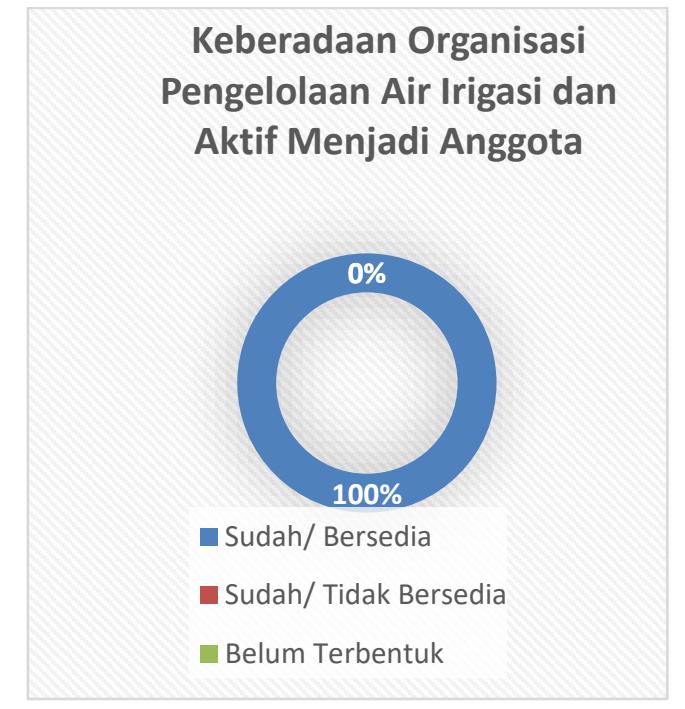

Gambar 8. Keberadaan Organisasi Pengelolaan Air Irigasi dan Aktif Menjadi Anggota

\section{E. KESIMPULAN DAN SARAN}

\section{Kesimpulan}

1. Hasil analisis menunjukkan bahwa masyarakat sepenuhnya mendukung program pembangunan DI. Bendo. Hal tersebut dikarenakan masyarakat merasa akan mendapatkan dampak positif dari kegiatan tersebut.

2. Persepsi Masyarakat atas Dukungan terhadap rencana Pembangunan Jaringan Irigasi D.I. Bendo adalah $100 \%$ warga mendukung atas rencana kegiatan tersebut. Keberadaan Jaringan Irigasi oleh petani dinyatakan Sangat Bermanfaat sebesar 90\%, dan Bermanfaat $10 \%$. Sehingga secara umum petani menganggap bahwa keberadaan Jaringan Irigasi Sangat Bermanfaat.
3. Warga/masyarakat bersedia melepas lahannya untuk kepentingan Pembangunan Jaringan Irigasi dan bersedia berpartisipasi secara Gotongroyong dalam menjaga dan merawat Jaringan Irigasi, serta bersedia bekerjasama dalam pengaturan/pengelolaan Air Irigasi.

\section{Saran}

Berdasarkan hasil penelitian dan pengamatan, disarankan beberapa hal sebagai berikut:

1. Komunikasi terhadap masyarakat sangat penting untuk menarik persepsi positif dan menghindari persepsi negatif akibat kesalahpahaman. Oleh karena itu, pada tiap tahapan kegiatan rehabilitasi, sosialisasi dan informasi kepada masyarakat perlu dilakukan.

\section{DAFTAR PUSTAKA}

Atkinson \& Hilgard. 2011. Psychology: An Introduction. Cengage Learning India Pvt Ltd

Kementerian Pekerjaan Umum. 2013. Standar Perencanaan Irigasi. Republik Indonesia.

Mawardi, Erman. 2007. Desain Hidraulik - Bangunan Irigasi. Alfabeta: Bandung, 2007, h. 7. 
Republik Indonesia. 2006. Peraturan

Pemerintah Republik

IndonesiaNomor 20 Tahun

2006TentangIrigasi.

Sosrodarsono, S. 1999. Hidrologi

Untuk Pengairan. Pradnya

Paramita, Jakarta.

Suhardjono. 1994. Kebutuhan Air Tanaman. Institut Teknologi

Nasional, Malang. 
